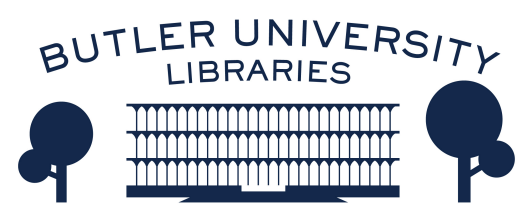

Journal of Hindu-Christian Studies

January 2008

\title{
Book Review: "Bourgeois Hinduism, Or the Faith of the Modern Vedantists"
}

Brian K. Pennington

Follow this and additional works at: https://digitalcommons.butler.edu/jhcs

Part of the Religion Commons

\section{Recommended Citation}

Pennington, Brian K. (2008) "Book Review: "Bourgeois Hinduism, Or the Faith of the Modern Vedantists"," Journal of Hindu-Christian Studies: Vol. 21, Article 23.

Available at: https://doi.org/10.7825/2164-6279.1422

The Journal of Hindu-Christian Studies is a publication of the Society for Hindu-Christian Studies. The digital version is made available by Digital Commons @ Butler University. For questions about the Journal or the Society, please contact cbauman@butler.edu. For more information about Digital Commons @ Butler University, please contact digitalscholarship@butler.edu. 
this work forcefully reminds us that a helpful way to enter into the ethos of a religious tradition is through its narrative tradition. Hindus and Christians need to share with one another their respective hagiographies that offer multiple points of contact between the two traditions. Second, it affirms the fact that the religious heritage of every religion belongs to the jointly-owned wealth of the whole of humanity. Such a view opens people of all religions to access, enjoy, and be enhanced by Tamil Saivism. Once such common heritage is acknowledged, one is compelled to question any particular and narrowly defined religious identity as a requirement for the enjoyment of a particular religious tradition. Third, an easy access to Hindu religious tradition through works of this kind offers to all religionists especially Christians - a vision of the one "who rules over earth and heaven, by whatever name he is known."

M. Thomas Thangaraj

Emory University, Atlanta, GA.

\section{Bourgeois Hinduism, Or the Faith of the Modern Vedantists. Brian A. Hatcher. New York: Oxford University Press, 2008, 226 pp.}

"ON the evening of September 29, 1839, a small group of earnest young men met in a small room on the premises of the Tagore mansion in north Calcutta." This unassuming opening to Brian A. Hatcher's most recent work on religion in colonial Calcutta gives little indication that the book that follows, covering the origins and evolution of an almost-forgotten religious society, might compel us to reconsider the most commonly told story of the birth of modern, reformist Hinduism. Through his discovery, translation, and analysis of the founding discourses of the Tattvabodhini Sabha (TruthPropagating Society) and his reconstruction of the evolution of that group's major ideas, Hatcher has unsettled our understanding of the religious milieu of Calcutta in the period following the death of modern Hinduism's most famous architect, Rammohan Roy. Canonical history generally traces an uninterrupted development of neo-Vedanta that begins with Roy working out his insights in a climate of dialogue and debate with Islam, Unitarianism, and evangelical missionaries in Calcutta. Steady success led, this version goes, to the mid-century diffusion of reforming Hinduism. The most significant revision to our previous set of ideas about the emergence of modern Hinduism is this book's resituation of Roy himself. The book deals with Roy in only a single, preliminary chapter, as a deceased reformer whose institutional legacy, the Brahmo Samaj was languishing and straying from its founding principles until the Tattvabodhini Sabha and
Debendranath Tagore, its guiding force, later revived his memory as their founding inspiration considerably after the fact.

Hatcher characterizes the Tattvabodhini Sabha as an independent and initially more successful movement, born from the religious longing of Debendranath. His experience and spiritual quest were also characteristic of a class of men at the forefront of a commercial revolution that was taking place in Calcutta. This class, called bhadralok in Bengali, possessed or acquired the necessary connections and educations that enabled them to benefit from the expansion of the British Raj, some materially, some merely socially. And while many bhadralok were able also to convert their successes into concomitant markers of status recognized by both Hindu and British society, they seem to have experienced significant dislocation from traditional religion and society. The rationalist, monotheistic, scripturally anchored, morally rigorous, and anti-idolatrous faith of such groups as the Tattvabodhini Sabha and the Brahmo Samaj fulfilled those longings with a religious ideology perfectly suited to the social and intellectual circumstances of this new class.

Although the Brahmo Samaj (founded in 1828) preceded the Tattvabodhini Sabha by more than a decade, after Rammohan's death in England in 1833, the society fell into a period of relative obscurity and inactivity until the Tattvabodhini Sabha agreed to manage its affairs in 1843. In the preceding two or three years, 
Brahmo worship had only begun to attract significantly higher attendance, Hatcher argues, as a result of the environment stoked by the (until then) more successful Tattvabodhini Sabha. Debendranath's autobiography tells us that when he witnessed an idolatrous invocation of Rama as an avatar of Vishnu at a Brahmo service, he was moved to reinvigorate the society according to the rationalist and nonidolatrous principles of Rammohan. The interests of the two societies merged, sewing the seeds for the ironic eventual disappearance of the Tattvabodhini Sabha, which had become superfluous with the great success of the Brahmo Samaj during the middle decades of the century.

Hatcher joins those who in recent years have promoted an appreciation of middle-class Hinduism as "real" religion, not just the tepid devotions of the upwardly mobile. A great strength of Hatcher's work as a whole, and this book in particular, is his ability to articulate the moral and cosmological contours of what he calls "bourgeois Vedanta" (or, borrowing from Rammohan himself, the spirituality of the "godly householder") in such a way that his readers come to comprehend what, from another point of view, might look like the barelydisguised rationalizations of a lifestyle and religiosity that are decidedly middle-class. Hatcher achieves these insights without a hint of irony or cynicism and indeed with a real sensitivity to the spiritual longings of a privileged elite.

Members of SHCS may find chapter five, "Missionaries and Modern Vedantists" of the greatest interest. Here Hatcher undoes some prior historical theorizing about the birth of the Tattvabodhini Sabha that attributed its origins to an anxious concern to stem the tide of highprofile conversions to Christianity in the 1830 s and 1840 s that had scandalized Calcuttan society. In particular, the success of Scottish missionary Alexander Duff and his disciple Krishna Mohan Banerjea, and the radical rationalism personified some years earlier by
Young Bengal and Henry Louis Derozio deeply troubled both orthodox and reforming Hindus. Historians such as David Kopf and M. M. Ali had previously seen the Sabha as an overt attempt to respond to these conversions with a spiritual "halfway house" that would offer an attractive alternative to these other two dangers. Hatcher makes it clear that the open rivalry between the sabha and missionaries working in Bengal dates to the same later period as the group's post facto adoption of Rammohan Roy as spiritual father and corroborates his detection of a rapid crystallization of group purpose and identity at this time.

Many readers will find the last three chapters the most compelling. In these Hatcher translates the discourses of the Tattvabodhini Sabha. Published under the title Sabhyadiger Vaktrta, each of these pieces had been originally delivered during one of the society's meetings in its first year, but in published form they were signed only according to an obscure system of initials. Hatcher appears not only to have made this important and illuminating text public, but to have identified the authors of most of its discourses. If his identifications are correctand his case on most of them is strong-we have in the Sabhyadiger Vaktrta the earliest extant writings from such important nineteenth-century figures as Debendranath Tagore himself and Isvaracandra Vidyasagara, as well as unseen writings by the rationalist Aksayakumara Datta and the Brahmo Samaj custodian Ramacandra Vidyavagisa. In these discourses we find an emergent neo-Vedanta and a testing ground for the concepts and vocabulary that will define later Brahmo spirituality. The critical apparatus that follows, particularly the glossary of terms and their English translations, is an important contribution in itself from a book that sheds important new light on a much-examined chapter of modern Indian history.

Brian K. Pennington

Maryville College 